\title{
Analysis of surface changes in the Wałbrzych hard coal mining grounds (SW Poland) between 1886 and 2009
}

\author{
Jan BLACHOWSKI ${ }^{1, *}$ and Wojciech MILCZAREK ${ }^{1}$ \\ 1 Wrocław University of Technology, Faculty of Geoengineering, Mining and Geology, Na Grobli 15, 50-421 Wrocław, Poland
}

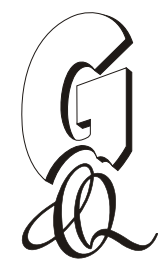

Blachowski, J., Milczarek, W., 2014. Analysis of surface changes in the Wałbrzych hard coal mining grounds (SW Poland) between 1886 and 2009. Geological Quarterly, 58 (2): 353-368, doi: 10.7306/gq.1162

\begin{abstract}
Underground coal mining causes surface changes such as subsidence and land use transformations. The knowledge of the character of subsidence in both the past and present provides useful information, e.g. for spatial development. This paper presents a methodology of determining surface height changes based on cartographic modelling in geographic information system (GIS) for an old mining site. It has been applied in two test areas of a former coal basin in the Wałbrzych region (SW Poland) characterized by complex geological and mining conditions. Surface changes have been determined based on available topographic maps of this area for a period of 123 years (1886-2009) as the result of a set of interpolation and map algebra operations. The elevation values reach 52 and $63 \mathrm{~m}$ for areas $A$ and $B$, respectively, and the maximum subsidence values determined in GIS are $24 \mathrm{~m}$ for study area $\mathrm{A}$ and $36 \mathrm{~m}$ for area $\mathrm{B}$. The former are associated with mining waste dumps. These results have been compared with the results of predictions based on the empirical Knothe theory of subsidence calculations using spatial statistics parameters. It has been found that Knothe theory-based modelling produces lower subsidence values and more uniform subsidence surface than the applied method based on the actual elevation data. This may be due to either the values of coefficients of subsidence used in the Knothe modelling method or the complex and complicated mining conditions (numerous overlying and inclined coal layers) of the Wałbrzych Coal Basin. The calculated surface height changes for the analysed period are presented graphically and described.
\end{abstract}

Key words: coal mining, subsidence, spatial analysis, DEM.

\section{INTRODUCTION}

Underground mining of coal deposits causes, among other things, surface deformation such as subsidence and land use transformations. Mining-induced land transformations include development of large volumetric objects, e.g. waste material dumps, settlement ponds and other types of features. Mining activity also influences land use change over time.

In general, underground mining-generated surface deformations can be divided into continuous and discontinuous. The continuous deformations are characterized by a smooth deformation pattern, whereas discontinuous deformations, usually associated with mining of shallow deposits or numerous levels, produce sinkholes or linear faults. The character and extent of surface subsidence varies depending on the type of mining method, depth of mineral extraction and period of mining. In the case of underground coal mining, a subsidence basin develops to grow in size with the progress of mining over time. Deformation of mining terrains continues after the end of mining. It usually diminishes in time and is often called secondary subsidence.

\footnotetext{
* Corresponding author, e-mail: jan.blachowski@pwr.wroc.pl
}

Received: August 26, 2013; accepted: March 16, 2014; first published online: April 10, 2014
Therefore, studies of former mining sites are equally important as monitoring of active mining operations because old mines can cause problems on the surface even many years after the end of mineral extraction. These problems include: secondary subsidence caused by delayed response of the rock mass or destruction of underground workings, environmental issues such as mine water pollution, inundation on subsided terrains due to groundwater level rise, as well as partial uplift of the ground (Preusse et al., 2008). For example, information on spatial and temporal characteristics of the mining-induced subsidence is important for planning revitalization and new development of former mining areas.

The difficulties with studying former mining sites arise from the fact that the necessary data may not be readily available, i.e. mine plans might have been lost or are in a paper format and observations (geodetic) of surface subsidence might have been stopped.

This paper presents a proposition of analysing the effect of long-time hard coal underground mining on the surface based on spatial modelling in Geographic Information Systems (GIS). This research has been carried out in the area of former underground coal mines in Wałbrzych (SW Poland; Figs. 1 and 2). We have proposed a data source and a GIS-based processing using the spatial interpolation and map algebra concept (Tomlin, 2008) that provide quantitative information on surface deformation of mining terrains for a period of mining operations (1886-2009) when other sources of surface height changes were unavailable. This method also provides results for com- 


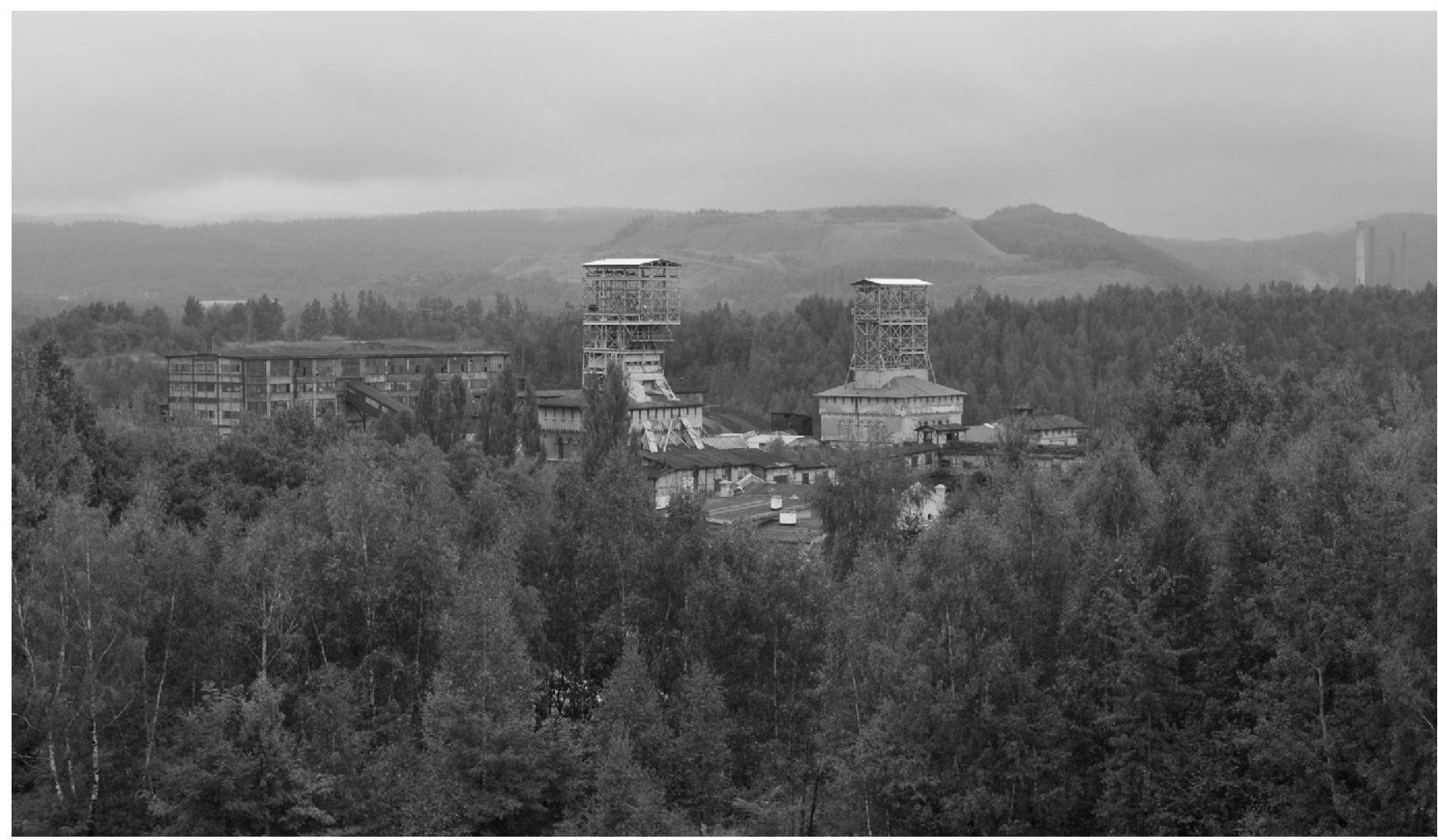

Fig. 1. The remains of the Thorez/Julia mine surface infrastructure - winding towers and waste dumps (in the background)

parison with predictions of subsidence based on the Knothe theory (Knothe, 1984; Kratzsch and Fleming, 2011).

Nowadays, GIS and the associated spatial analysis methods are used, more and more often, to study and assess the character of changes occurring on the ground surface and to identify areas of possible hazards due to underground mining (Mathey, 2013). GIS is especially effective in processing numerous and large datasets, e.g. remote sensing data and digital elevation models (DEM). The applications of GIS in mining terrain deformation studies concern mostly active mining sites. Research in this field has been progressing in Asia (South Korea, China and Japan), Australia and in Europe: in Poland, Germany, France, Italy and other countries. In South Korea, Oh and Lee (2010) tried to assess ground subsidence spatial hazard near abandoned underground coal mine with various prediction models. Oh et al. (2011) then proposed a methodology for developing ground subsidence hazard maps near abandoned coal mines using frequency ratio and sensitivity analysis to produce ground subsidence hazard index with the aid of GIS. The ground subsidence susceptibility mapping with Artificial Neural Network in GIS was studied by Lee et al. (2012). Before that, Oh and Lee (2011) had facilitated with GIS the spatial ground subsidence hazard mapping using models that based on frequency ratio (FR), logistic regression (LR) and an artificial neural network (ANN). Studies in Japan and China concentrated on combining a stochastic model of ground movements implemented by a computational program and GIS used to fulfil the spatial-temporal analysis function (Esaki et al., 2008). Djamaluddin et al. (2011) used GIS to facilitate subsidence prediction using the empirical Knothe method and application of fuzzy logic to identify damage classification zones. The subsidence susceptibility maps based on fuzzy relations were also studied by Choi et al. (2010). Australian experiences concern, for example, applicability of the satellite-based Synthetic Aper- ture Radar Interferometry (InSAR) as a method for monitoring of surface subsidence caused by mining of underground ore deposits with the aid of GIS (Jarosz, 2005), and the GIS-based Weights of Evidence technique to derive a model of rockfall potential associated with mining-induced subsidence (Zahiri et al., 2008). Researchers from Italy tried a GIS and multicriteria approach to assess vulnerability to ground deformation phenomena (Stecchi et al., 2012). Samsonov et al. (2013) have proposed a new InSAR time series method for studies of ground deformation associated with post-mining activity at the French-German border. In Poland, mining ground subsidence was studied by Malinowska and Hejmanowski (2010) and Malinowska (2011) who have proposed a combination of expert systems and GIS in building a damage risk assessment on mining-induced areas in Poland. Jędrzejec et al. (2008) used GIS databases for numerical prediction of rock mass and surface deformation based on the Knothe theory. Blachowski (2008) and Blachowski and Stefaniak (2012) focused on the development of geoinformation system for abandoned underground coal mines, and automation of spatial analyses in GIS.

However, the measurement techniques and analytical methods described above could not have been used in this case as the available information on elevation change concerned both 19th century analogue cartographic and 21st century DEM and digital topographic data. As mentioned earlier, application of GIS spatial modelling to these data provided the capability to assess the extent and magnitude of mining terrain subsidence and analysis of land development in the case when other sources of height measurements were unavailable (i.e., geodetic levelling measurements), whereas remote sensing observations, e.g. various Interferometric SAR or satellite GPS observations, became available in the last decades only. The applied methodology of incorporating spatial interpolation techniques and raster calculator (map algebra) operations in GIS 


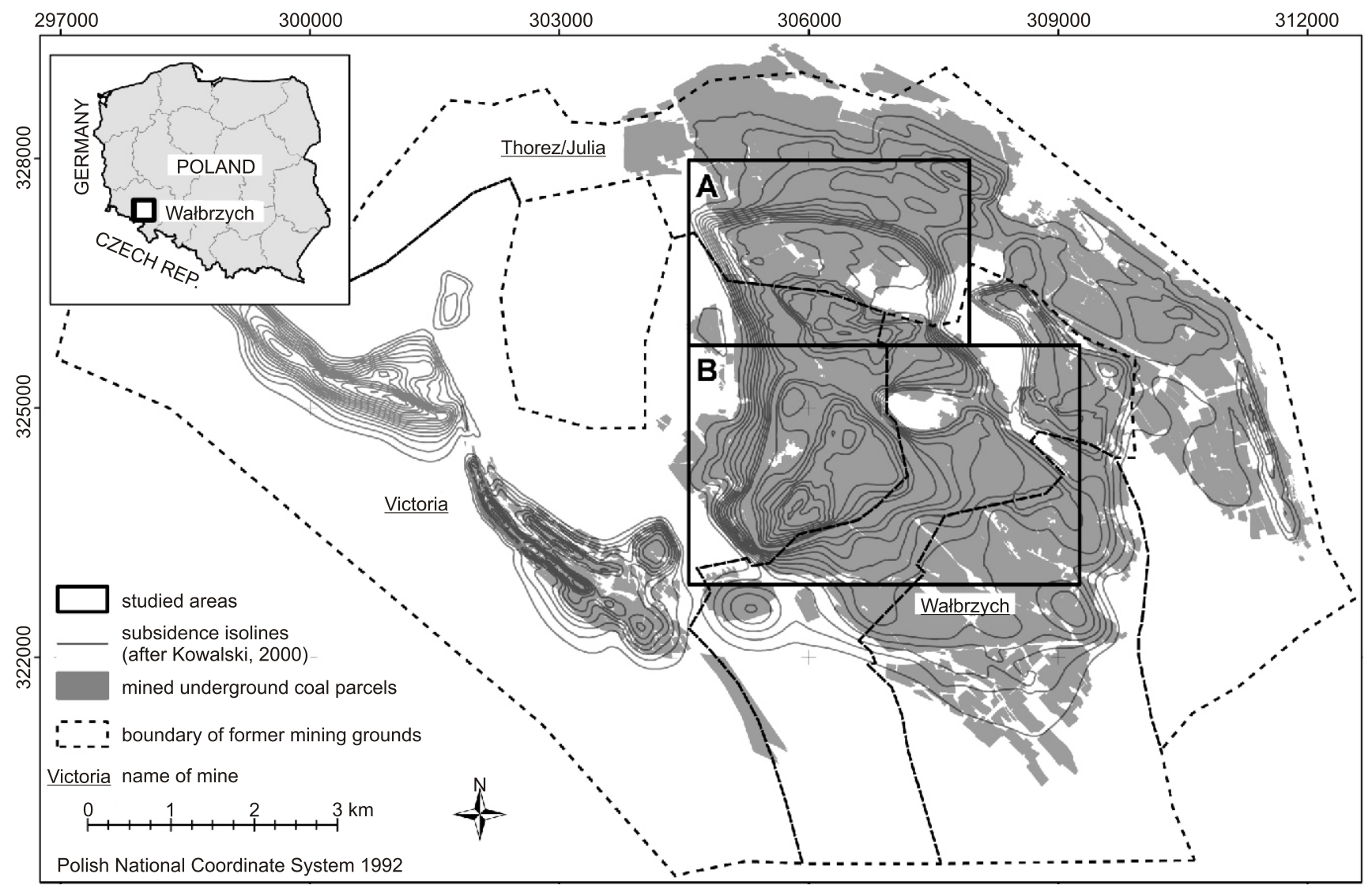

Fig. 2. Location and boundaries of the former mining grounds in Wałbrzych, extent of underground workings, extent of predicted subsidence zones and location of study areas

provided quantitative information on surface deformation for a period of more than a century.

In this paper, the results of subsidence analysis concerning a period of 123 years of underground coal mining are described. The results of GIS modelling provided quantitative information based on actual elevation change data and were compared with the results of empirical calculations based on the Knothe theory.

\section{STUDY AREA}

The area of interest is the Wałbrzych Coal Basin as part of the former Lower Silesian Coal Basin located in and around the city of Wałbrzych in SW Poland. Underground mining of coal deposits characterised by complex mining and geological conditions (numerous steeply inclined and thin coal beds) took place there for several hundred years and ended in the late 1990s. Long-time extraction of coal had caused changes on the surface, whose effects are visible in the local landscape to this day (Fig. 1). In the period after World War II, three underground mines were in operation: Thorez/Julia, Victoria and Wałbrzych. The following mining systems were used: long-wall and caving (predominant) and long-wall with various forms of fill (pneumatic, dry, dry with material from dead drifts). The locations of underground coal levels and boundaries of the former mining grounds are shown in Figure 2.
GEOLOGY

In terms of geology, the former mines in the Wałbrzych area are located in the Wałbrzych Basin - a geological structure constituting the NE part of the Intra-Sudetic Basin. It is differentiated in terms of the continuity of deposits, thickness of deposited formations and tectonic conditions (Kożuchowicz and Oprychał, 1984). The main structural units of the Wałbrzych Basin are: the Jabłowa anticline, the smaller Gorce and the larger Sobięcin synclines, and the Chełmiec rhyolite laccolith separating the two synclines. The area is composed predominantly of sedimentary clastic deposits, as well as volcanic rocks such as: porphyry, melaphyre and tuff. The complicated geology is the results of intrusive and compressive tectonic activity of the Asturian Phase (Serdyńska-Iwaniuk, 1984). Most of faults trend from the NW towards SE with the influence of the Chelmiec intrusion clearly marked by longitudinal and latitudinal faults. The throw of the main faults reaches $300 \mathrm{~m}$. In addition, there are numerous local faults in the hard coal-bearing layers, with throws attaining several metres (Kominowski, 2000).

The Wałbrzych Basin is an example of limnic-type coal basin, where the deposition took place in intra-mountainous sedimentary basins. The result is a mixed exogenous - endogenous coal deposit. The coal-bearing layers are associated with three of the four lithostratigraphic Pennsylvanian complexes: the Žaclér̆ formations, the Biały Kamień and the Wałbrzych formations. Eighty coal layers have been identified there, including 48 in the Žaclér Formation and 30 in the Wałbrzych Formation. 
The stratal dips are towards the centre of the Wałbrzych Basin, ranging from several to over $30^{\circ}$, and from 30 to $60^{\circ}$ in the outskirts (Kominowski, 2000).

\section{PREVIOUS RESEARCH}

The studies of ground surface subsidence in the Wałbrzych Coal Basin were carried out at various times and in various parts of the mining grounds. They were based on periodic levelling measurements in selected areas. The most comprehensive study was performed by Kowalski (2000). It focussed on the determination of the effects of underground mining on ground deformation using empirical modelling based on the Knothe theory. The theory assumes that the underground mining-induced subsidence profile of the surface can be described by the Gauss function (Knothe, 1984). Experiences show that it gives good results for horizontal deposits, but its application in complicated conditions (multiple levels, inclined levels) requires additional parameters to be included, and provides approximate results (vide Białek and Mielimakka, 2001; Kowalski, 2008; Majcherzyk and Kryza, 2013). Using this method, Kowalski and Jędrzejec (2000) calculated theoretical values of subsidence for the entire period of mining and for the period after World War II. In the first case, the predicted subsidence amounted to $22 \mathrm{~m}$, and in the latter $-9 \mathrm{~m}$. In addition to mining terrain deformation, the area was also analysed in terms of land use changes. The studies done by Wójcik (2006, 2008) characterized anthropogenic, mining-triggered changes in the local topography and land use. He focused on the final years of mining from 1975 to 1996 and noted that the greatest surface changes occurred in the period 1975-1990, when a $35 \mathrm{~km}^{2}$ area was affected predominantly due to the increase in use of long-wall and caving mining systems.

\section{MATERIALS AND METHODS}

In this study, the cartographic modelling methodology in geographic information system (GIS) has been applied to calculate mining terrain subsidence. Cartographic modelling is a general method for analysis and synthesis of spatial data, which uses algebraic operations, in which single-factor maps (e.g., elevation) are regarded as variables that can be manipulated using a set of cartographic functions (e.g., slope calculation; Tomlin, 2008). Raster data formats, in which the surface is divided into regular cells with assigned values, are often used in these analyses.

The research was aimed at identification of the ground elevation changes and comparison of these changes with the subsidence zones predicted with the Knothe theory-based method by Kowalski (2000). The proposed methodology uses digital elevation models (DEM) from topographic maps to calculate elevation differences between those DEMs and the DEM obtained from orthoimages. The study covers a period of 123 years (from 1886 to 2009). In an accompanying analysis, areas of land transformations were identified and compared with the present-day development of the area.

The basic input source data included: the oldest available edition of German topographical map (sheet Waldenburg) from 1886 prepared at a scale of 1:25,000 (Fig. 3), German and Polish mining maps prepared at at scales 1:2000-1:5000 and representing underground coal production levels mined in the period 1800-1998, Polish topographical map prepared at a scale of 1:10,000 from 1995, orthoimage at a scale of $1: 26,000$ with $0.5 \mathrm{~m} /$ pixel resolution from 2009 , and a digital elevation model with $10 \mathrm{~m}$ horizontal and $1.5 \mathrm{~m}$ vertical resolution from 2009 . The reference vertical coordinate system is Kronsztad 86. The orthoimage and DEM were generated through photogrammetric processing of aerial photos and obtained from the Dolnośląskie Voivodeship Documentation Centre of Geodesy and Cartography. The main source data used are listed in Table 1. All of the spatial data processing tasks have been performed using the ESRI ArcGIS Arclnfo v.10 software.

In the first step, two areas of interest were selected based on the known locations of old underground mine workings and areas of the greatest subsidence determined from theoretical predictions using the modified Knothe theory (Kowalski, 2000). These areas, marked with letters $A$ and $B$ are shown in Figure 2. They are characterized by the greatest predicted subsidence values, significant land development (orthoimage) and differentiated topography.

The information on spatial location of underground workings has been extracted from the geoinformation system of the former Wałbrzych mines (Blachowski, 2008; Blachowski and Stefaniak, 2012). The system was developed to support studies on the behaviour of the surface of former mining grounds. In addition to data on geometry and location of underground coal levels and workings, it stores information on mining methods used and periods of mining for individual coal parcels. Other types of data in the system include: locations of geodetic benchmarks and levelling lines with results of periodic measurements, geology, locations of tectonic faults and protective pillars, as well as various cartographic materials (images of topographical, geological and mining maps, orthoimages, digital elevation models, etc.).

In the second step, input data for the analysis were pre-processed. It included georeferencing of topographical map from 1886 to a common coordinate system, and digitising of the map content. The following information has been digitised to a vector data format: contour lines, elevation points, linear infrastructure (roads, railway lines) and land use. The interval of digitised contour lines was $5 \mathrm{~m}$ and in some areas $2.5 \mathrm{~m}$.

Digital elevation models representing the surface elevation in 1886 has been generated using the interpolation method developed by Hutchinson (Hutchinson and Dowling, 1991) and designed to develop hydrologically correct digital elevation models.

The raster maps of the surface, as it was mapped in 1886 and 2009, were used to calculate surface height changes from 1886 to 2009 in the two selected areas A and B. The height changes were calculated by subtracting elevation values of the raster maps. Based on the accuracy of the DEM and of the digitised contour lines, the calculated height differences (ranging from -3 to $+3 \mathrm{~m}$ ) are regarded as insignificant based on error analysis results, and excluded from further studies. The calculated error amounted to $\pm 2.9 \mathrm{~m}$. The following formula was used [1]:

$$
S_{v}=\sqrt{S_{1}^{2}}+\cdots+S_{n}^{2}
$$

where: $S_{v}-$ total vertical error, $S_{n}-$ accuracy of input raster layer.

The horizontal error $\left(S_{h}\right)$ was assessed based on comparison of known location ( $x$ and $y$ coordinates) of a set of selected features, e.g. existing geodetic benchmarks and the location of points representing them in GIS, using the formula [2] (Bolstad and Smith, 1992): 


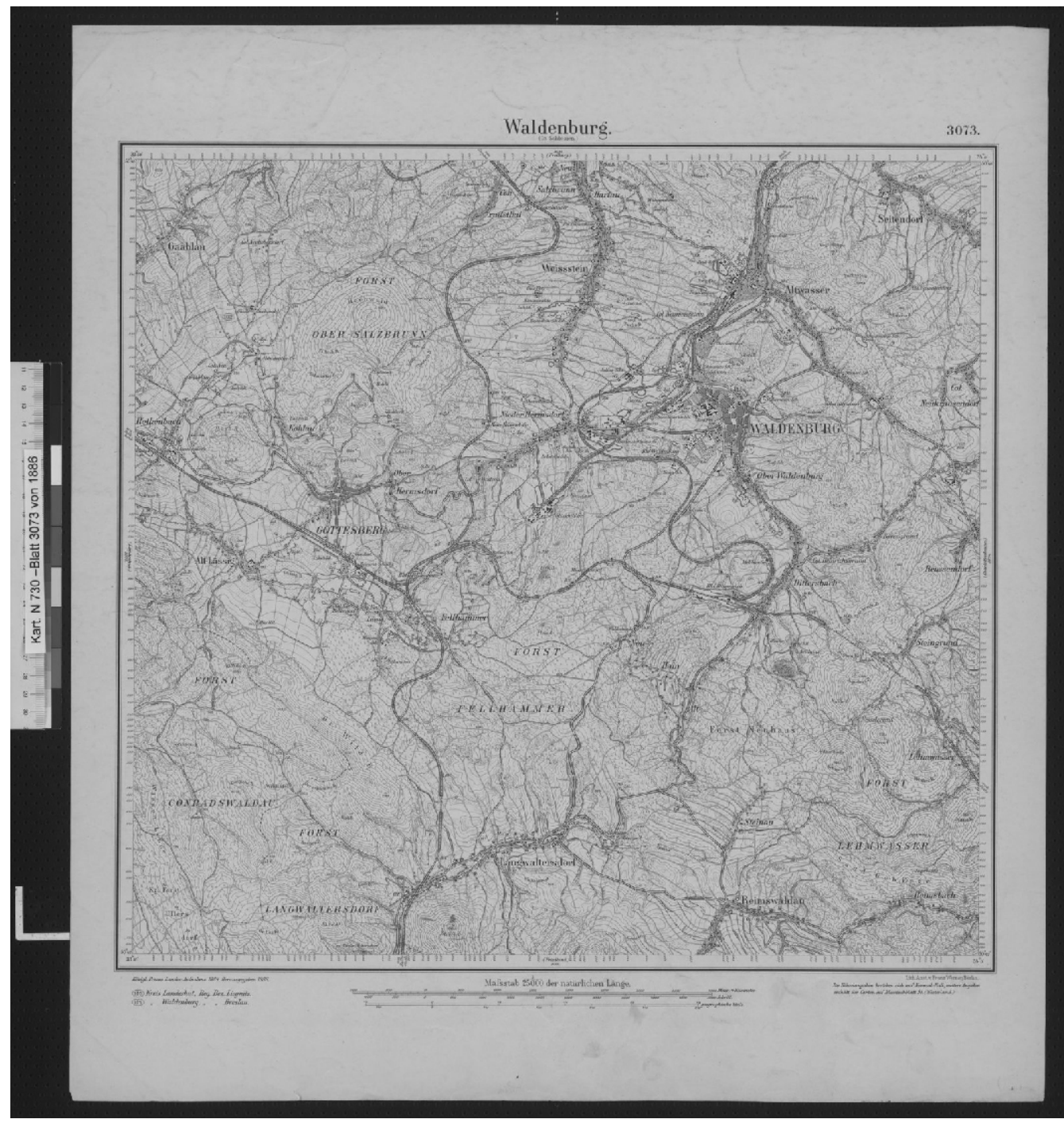

Fig. 3. Example topographical map used as source data

Characteristics of main source data

\begin{tabular}{|l|c|c|c|c|c|}
\hline No. & Name & Format & Scale/resolution & Location & Date \\
\hline 1 & Messtischblatt Waldenburg & $\begin{array}{c}\text { raster file (scanned } \\
\text { document) }\end{array}$ & $1: 25,000$ & $\begin{array}{c}\text { Staatsbibliothek zu Berlin - Preußischer } \\
\text { Kulturbesitz } \\
\text { Kartenabteilung }\end{array}$ & 1886 \\
\hline 2 & Mining Maps & $\begin{array}{c}\text { raster files (scanned } \\
\text { documents) }\end{array}$ & $\begin{array}{c}1: 2000 \\
1: 5000\end{array}$ & $\begin{array}{c}\text { State Mining Authority. Archive of Mine } \\
\text { Survey and Geological Documentation }\end{array}$ & until 1998 \\
\hline 3 & Subsidence Map & $\begin{array}{c}\text { CAD file, } \\
\text { GIS shapefile }\end{array}$ & - & Central Mining Institute & 2000 \\
\hline 4 & Digital Elevation Model & TIN, GRID & $\begin{array}{c}10 \mathrm{~m} \text { horizontal } \\
1.5 \mathrm{~m} \text { vertical }\end{array}$ & $\begin{array}{c}\text { Dolnoślaskie Voivodeship Documentation } \\
\text { Centre of Geodesy and Cartography }\end{array}$ & 2009 \\
\hline 5 & $\begin{array}{c}\text { Orthoimage at a scale of } \\
\text { with 0.5 m/pixel resolution }\end{array}$ & raster file & $1: 26,000$ & as above & 2009 \\
\hline
\end{tabular}




$$
S_{h}=\sqrt{\frac{S_{x}^{2}+S_{y}^{2}}{n}}
$$

where: $S_{h}$ - total horizontal error, $n$ - number of test points, $S_{x}$ - error in the $\mathrm{x}$ direction, $S_{y}$ - error in the y direction.

The calculated horizontal error is smaller than the resolution (40 $\mathrm{m}$ pixel size) of the resulting grid surfaces representing DEM.

The calculated height changes of the surface between 1886 and 2009 were compared with both subsidence values predicted by (Kowalski and Jędrzejec, 2000) and present-day orthoimage of the area.

The second, supplementary aspect of this study was to analyse the process of land transformation due to built-up area development. The spatial datasets representing developed areas (human settlements, industrial sites, waste land, etc.) were produced by digitising topographical map from 1886 and orthoimage from 2009. These data have been converted to raster format and used to determine and analyse the change in the extent of developed land in this period using GIS map algebra operations.

General scheme of the applied methodology is shown in Figure 4.

\section{RESULTS AND DISCUSSION}

\section{CHANGE OF SURFACE ELEVATIONS}

The raster maps showing the surface change in areas $A$ and $B$ for the 1886-2009 period, obtained from spatial interpolation and calculated by subtracting raster cell values of the two DEM raster maps of 1886 and 2009, are presented against the

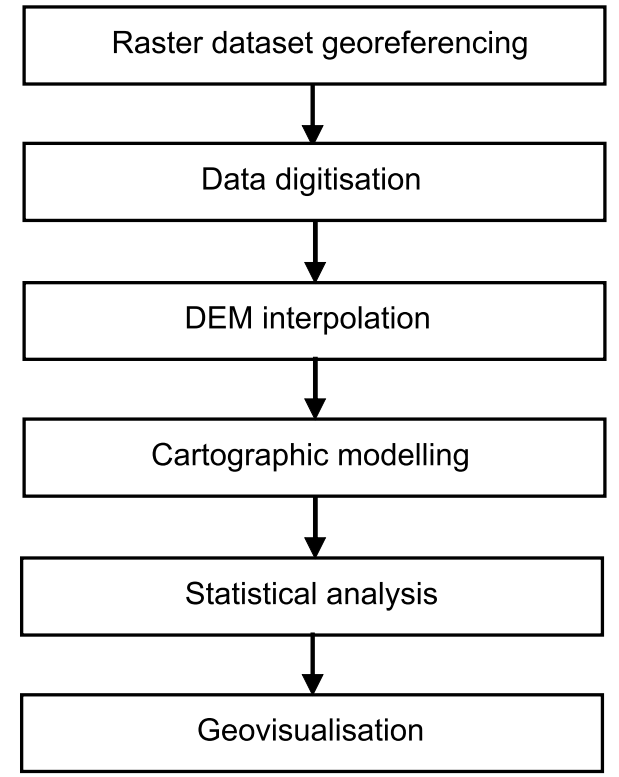

Fig. 4. Flowchart of the applied procedure

background of orthoimage in Figures 5 and 6, respectively. Warm colours represent elevated areas whereas cold colours subsided areas. The calculated maximum subsidence values reach $24 \mathrm{~m}$ in area $\mathrm{A}$ and $36 \mathrm{~m}$ in area $\mathrm{B}$. It corresponds to 0.2 and $0.3 \mathrm{~m}$ per annum, respectively. The maximum elevation values are 52 and $63 \mathrm{~m}$ for areas $A$ and $B$, respectively. In the former, $78.5 \%$ of the area has subsided and $29 \%$ of the total area has subsided by more than $12 \mathrm{~m}$ (dark blue regions). In the latter, $73.8 \%$ of the area has subsided and $8.2 \%$ has subsided by more than $12 \mathrm{~m}$ (dark blue regions). The elevated parts in both areas are associated with mining waste dumps.

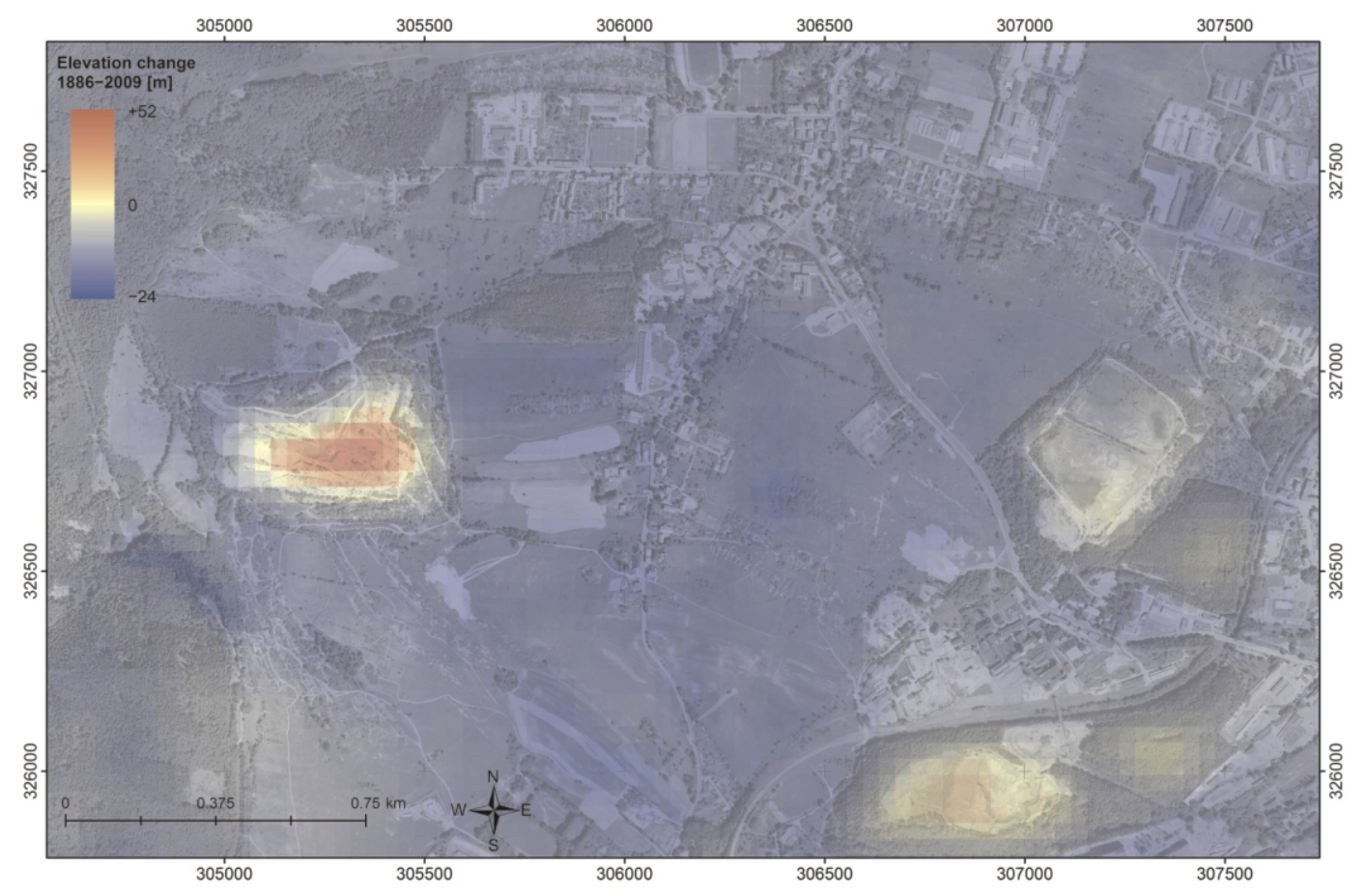

Fig. 5. Surface height changes for area $A$ in the 1886-2009 period 


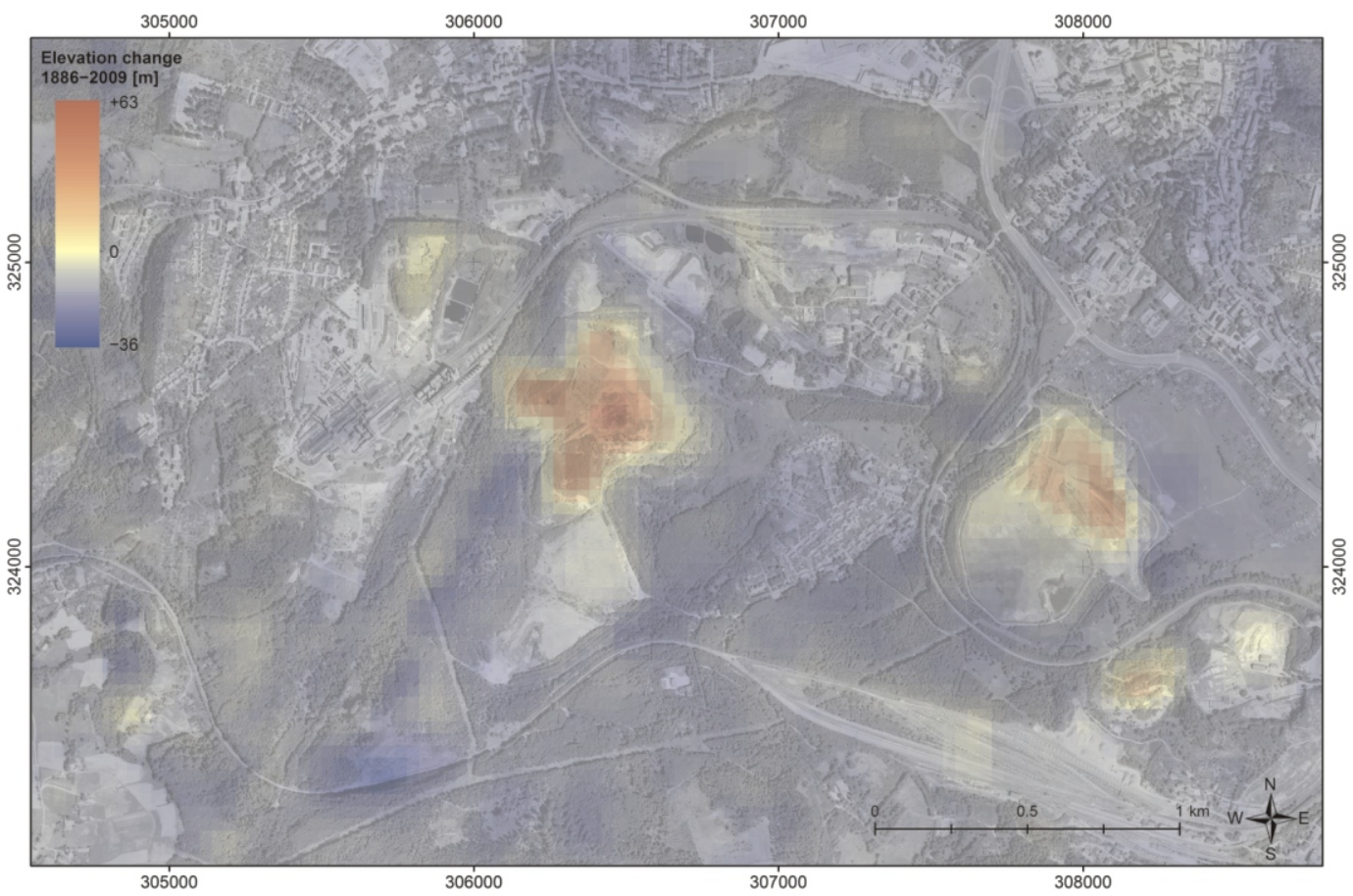

Fig. 6. Surface height changes for area B in the 1886-2009 period

DEM ANALYSIS IN GIS VERSUS MODELLING WITH THE KNOTHE THEORY OF SUBSIDENCE

The raster maps of surface height changes determined with interpolation and map algebra techniques based on topographical materials have been compared with raster maps representing subsidence predicted using the modified Knothe theory. Statistical information on this comparison is given in Table 2.

The raster map with $40 \mathrm{~m}$ pixel resolution, showing the results of surface height changes between 2009 and 1886 for area $A$, is presented in Figure 7. The negative change (subsidence) calculated by subtracting the two raster cell values is represented in greyscale, darker colours depict greater subsidence. The white area represents subsidence of $3 \mathrm{~m}$ or less and areas of positive change (elevated; e.g., dumps created or developed after 1886) excluded from the subsidence analysis. Figure 8 shows subsidence calculated by Kowalski and Jędrzejec (2000) using the modified Knothe theory and converted to raster format for the purpose of this analysis.

The subsidence values in this area predicted by Kowalski and Jędrzejec (2000) range between 1 and $18 \mathrm{~m}$, whereas the values obtained from raster layer subtraction vary from 3 to $24 \mathrm{~m}$.

Correlation between the two compared raster maps representing calculated and predicted subsidence is 0.90 , thus indi- cating direct relationship between their cell values. The correlation matrix has been calculated based on the two rasters statistical parameters as the ratio of the covariance between the two layers divided by the product of their standard deviations (ESRI, 2010). Comparison of these layers (Figs. 7 and 8) shows correlation between the zones of greatest subsidence (dark grey and grey areas marked with black ellipses). However, the subsidence distribution obtained with the two compared approaches yields different results in some parts of the study area. Direct comparison of the two DEM raster maps (excluding areas with values of $3 \mathrm{~m}$ and more) shows that the maximum difference between collocated cells is $\pm 12 \mathrm{~m}$, while the mean is $0.6 \mathrm{~m}$ with standard deviation of $3.8 \mathrm{~m}$. It indicates that the difference between the raster maps is not uniform over the area and there are areas of discrepancies visible, for example, in areas marked with dashed ellipses (Figs. 7 and 8). It shows that the actual surface change is not as uniform as that modelled with the Knothe method.

Figure 9 shows zones of positive change of heights (elevation) for area A, calculated from raster subtraction, and Figure 10 shows the present-day topography of the area (orthoimage). The white colour in Figure 9 represents elevation of up to $+3 \mathrm{~m}$ and areas of subsidence excluded from this analysis. The areas of calculated surface elevation differences be-

\section{Subsidence maps}

\begin{tabular}{|l|c|c|c|c|c|c|}
\hline & $\begin{array}{c}\text { Max. subsidence GIS } \\
\text { method [m] }\end{array}$ & $\begin{array}{c}\text { Max. subsidence } \\
\text { Knothe method [m] }\end{array}$ & $\begin{array}{c}\text { Max. difference } \\
\text { between rasters [m] }\end{array}$ & Mean [m] & Standard deviation & Correlation \\
\hline Area A & -24 & -18 & 12 & -0.6 & 3.8 & 0.90 \\
\hline Area B & -36 & -22 & 16 & -1.2 & 5.2 & 0.69 \\
\hline
\end{tabular}




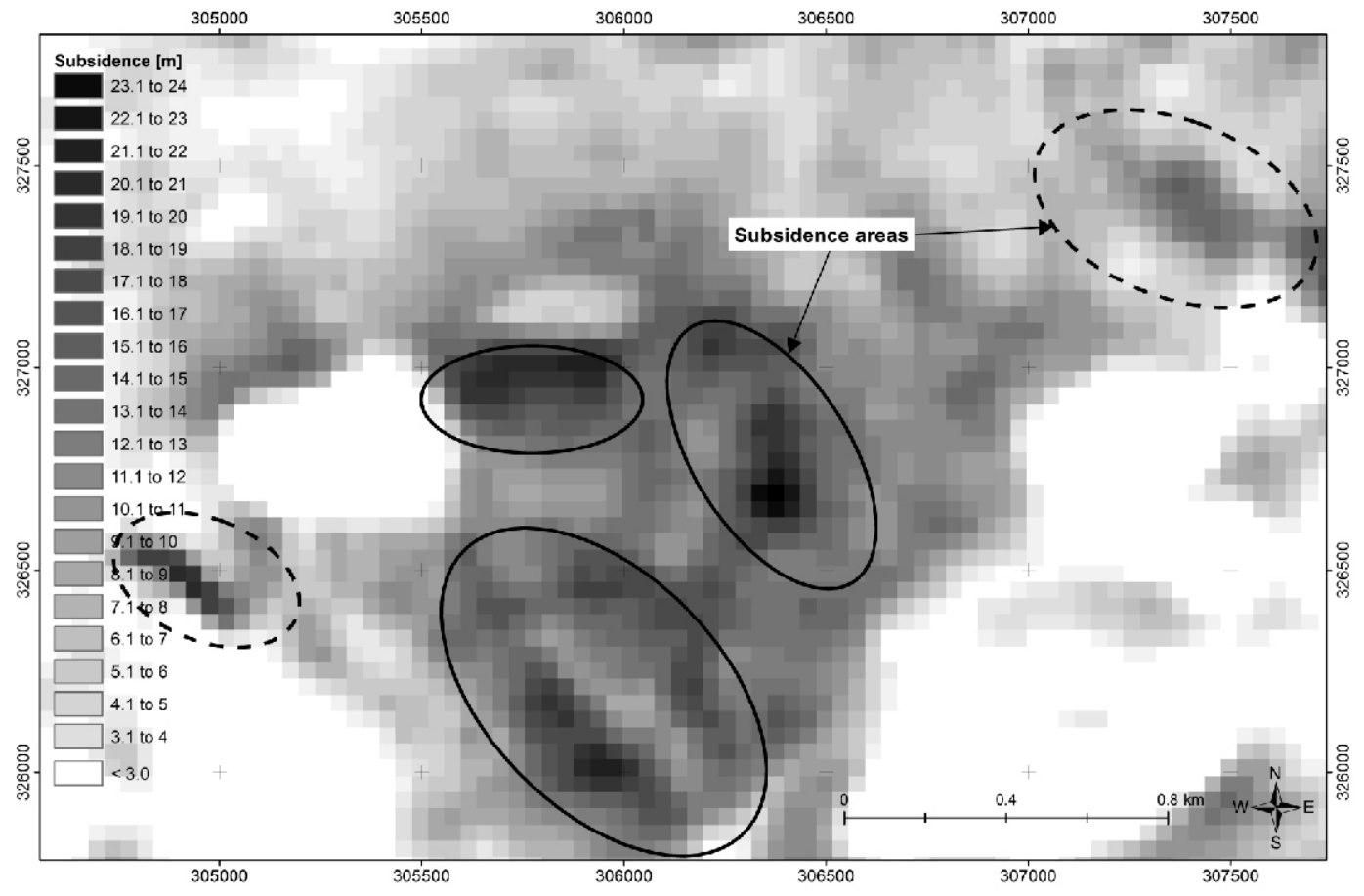

Fig. 7. Subsidence in area A, calculated from subtraction of DEM raster maps

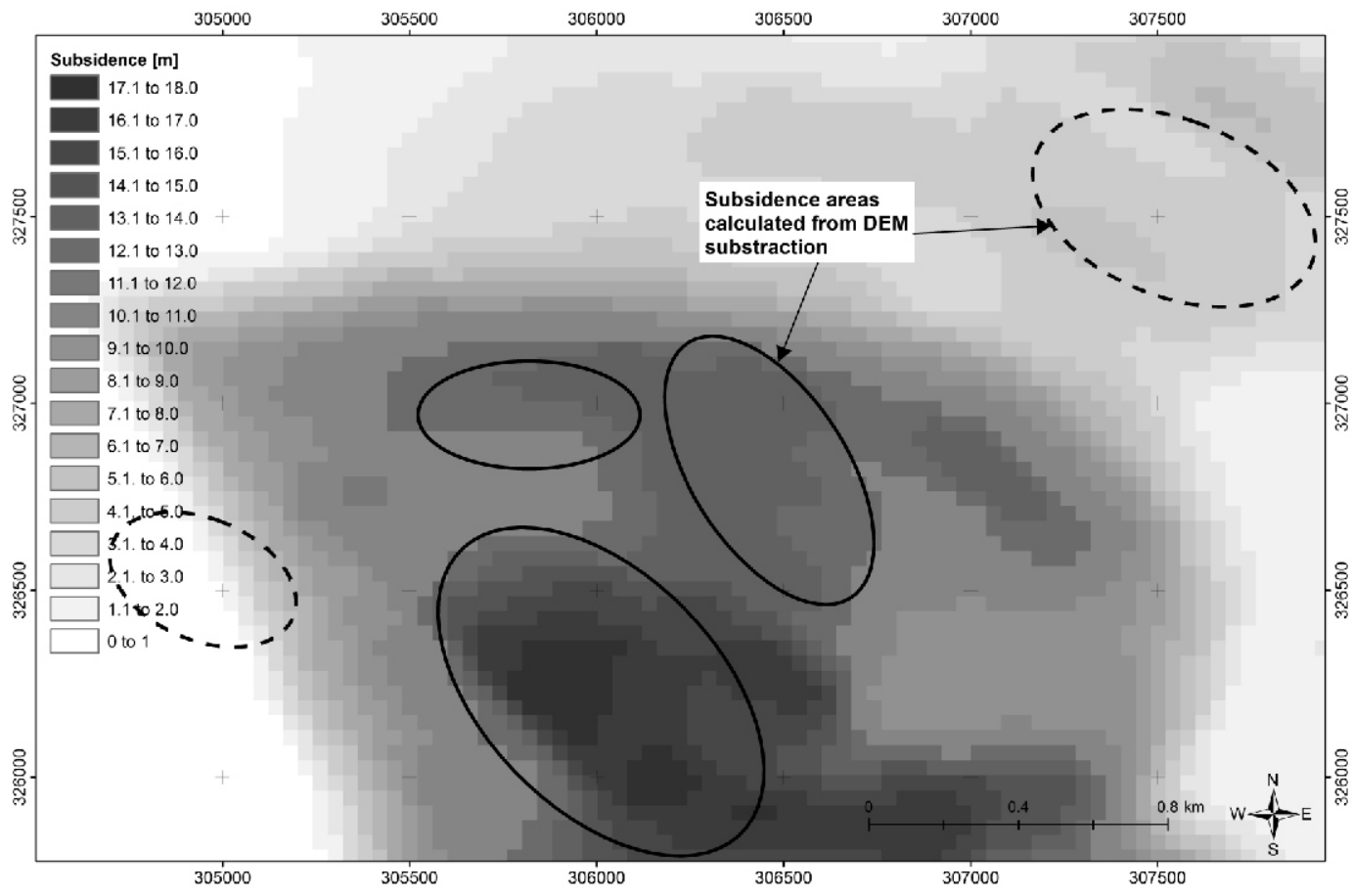

Fig. 8. Subsidence in area A, predicted using the modified Knothe method 


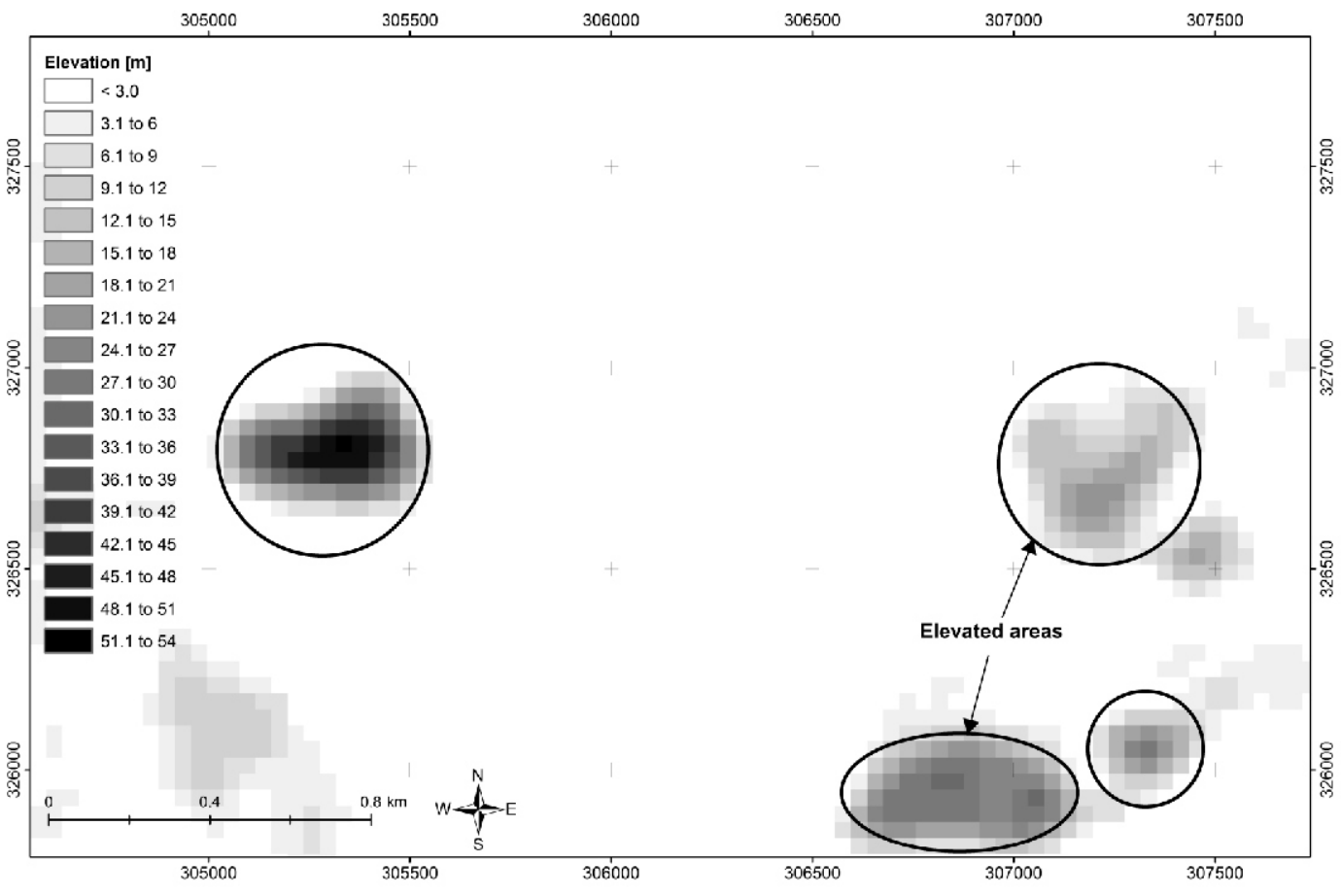

Fig. 9. Elevation in area $A$, calculated from subtraction of DEM raster maps

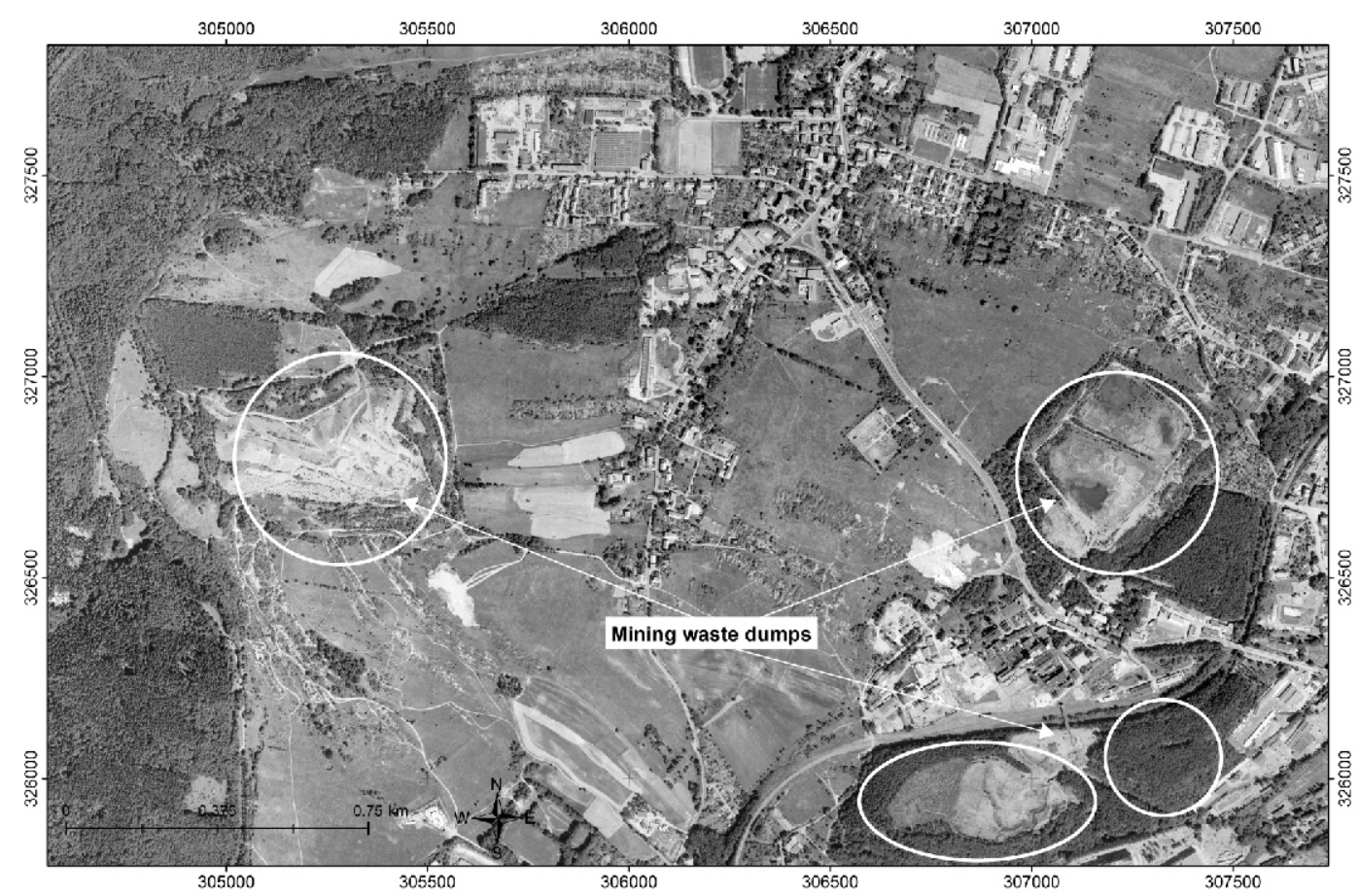

Fig. 10. Orthoimage showing present-day topography of area A 
tween 1886 and 2009 correspond to mining waste dumps that developed in area A during that period.

One must note that the development of mining waste dumps shown in Figures 9 and 10 has influenced the results of subsidence calculations based on subtraction of the 2009 and 1886 raster maps. The areas with identified surface elevation also experienced subsidence that was masked by a greater positive change of heights because of dump development.

The results of subsidence analysis for area $B$ are presented in Figures 11 and 12. The subsidence values predicted by Kowalski and Jędrzejec (2000) range from 1 to $22 \mathrm{~m}$, whereas the values obtained with the proposed GIS method reach $36 \mathrm{~m}$. This difference is greater than for area $A$ and, in our opinion, the explanation is the same as in the case of area $A$.

Correlation between the two compared raster maps representing calculated and predicted subsidence is 0.690 , thus indicating direct relationship between their cell values. The correlation matrix has been calculated based on the two rasters statistical parameters as the ratio of the covariance between the two layers divided by the product of their standard deviations (ESRI, 2010).

Comparison of these raster maps (Figs. 11 and 12) shows correlation between the zones of greatest subsidence (dark grey and grey areas marked with black ellipses). As in the case of area $A$, the subsidence distribution obtained with the two compared approaches yields different results in some parts of the study region, for example, in the zones marked with dashed ellipses (Figs. 11 and 12). Direct comparison of the two DEM raster maps (excluding areas with values of $3 \mathrm{~m}$ and more) shows that the maximum difference between collocated cells is $\pm 16 \mathrm{~m}$, while the mean is $-1.2 \mathrm{~m}$ with standard deviation of $5.2 \mathrm{~m}$. It indicates that the difference between the raster maps is not uniform and there are areas of discrepancies. These are visible, for example, in areas marked with dashed ellipses (Figs. 11 and 12). It shows that the actual ground movement is not as uniform as that determined with the Knothe method.

Figure 13 shows zones of positive change of heights (elevation) for area B, calculated from raster subtraction, and Figure 14 illustrates the present-day topography of the area (orthoimage). The white colour in Figure 13 represents elevation of up to $+3 \mathrm{~m}$ and areas of subsidence excluded from this analysis. In this case, the areas of calculated surface elevation differences between 1886 and 2009 correspond to present-day locations of mining waste dumps in area $B$.

Development of mining waste dumps (Figs. 13 and 14) has also influenced the results of subsidence calculations based on subtraction of the 2009 and 1886 raster maps. A profile along a line shown in Figure 14, running across the area that underwent subsidence and elevation in the considered period (1886-2009), is presented in Figure 15. Comparison of the profiles representing the surfaces in 1886 and 2009 gives an estimation of the amount of subsidence and the height of the mining waste dump developed during those times.

In our opinion, the values of subsidence obtained with the proposed, GIS based method, provide more accurate information on mining terrain subsidence in this area compared to those calculated with Knothe theory. The values of subsidence predicted with the method based on the Knothe theory are generally smaller, maybe due the values of coefficients of subsidence used in the Knothe modelling method. The main advantage of the Knothe method is good convergence of its results with field measurements of subsidence associated with mining of horizontal deposits. However, the method is difficult to use in areas of complex geological structure and complicated in terms of mining activity, i.e. numerous overlying and inclined coal deposits mined at different times, such as those of the Wałbrzych

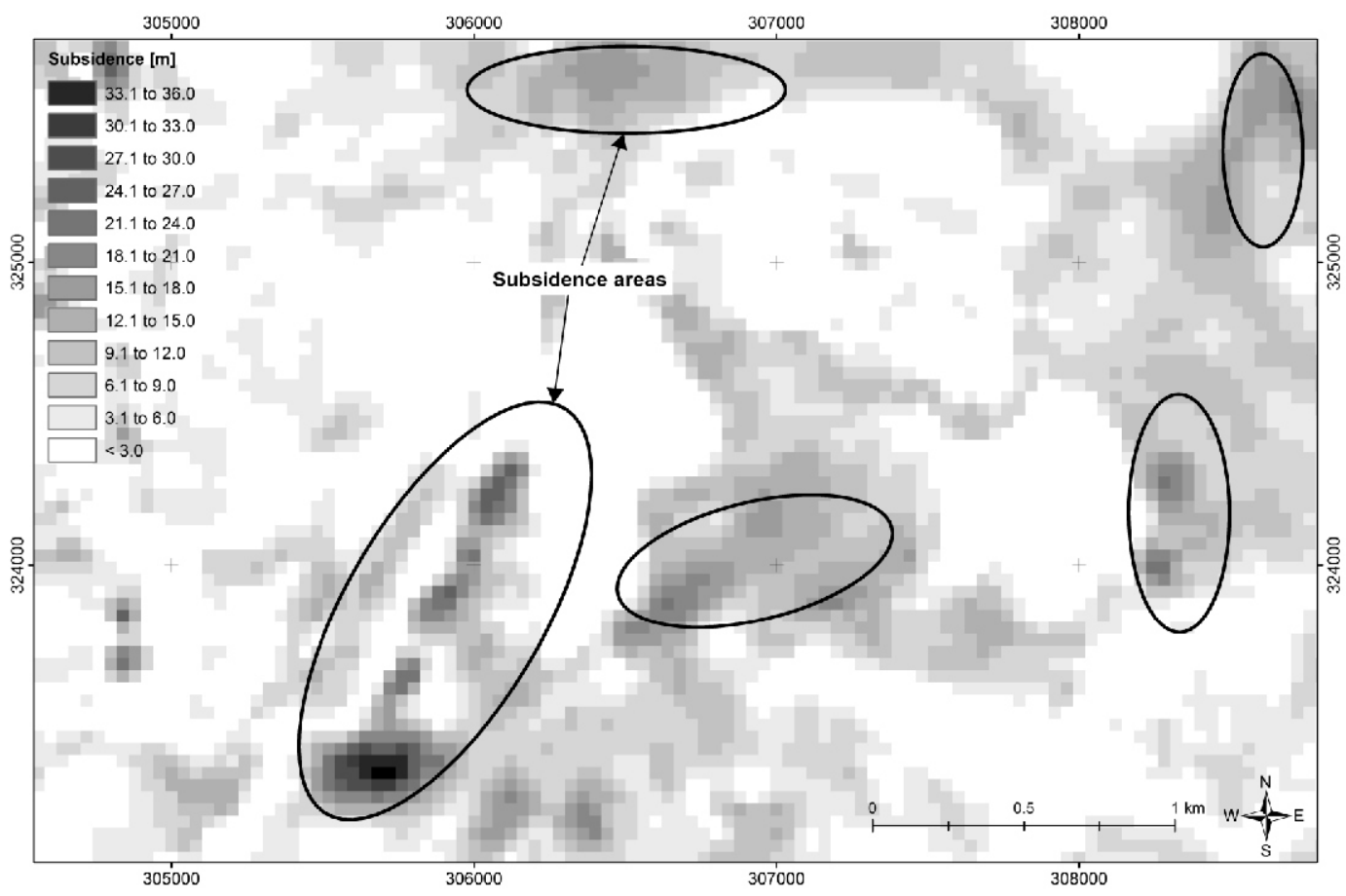

Fig. 11. Subsidence in area $B$, calculated from subtraction of DEM raster maps 


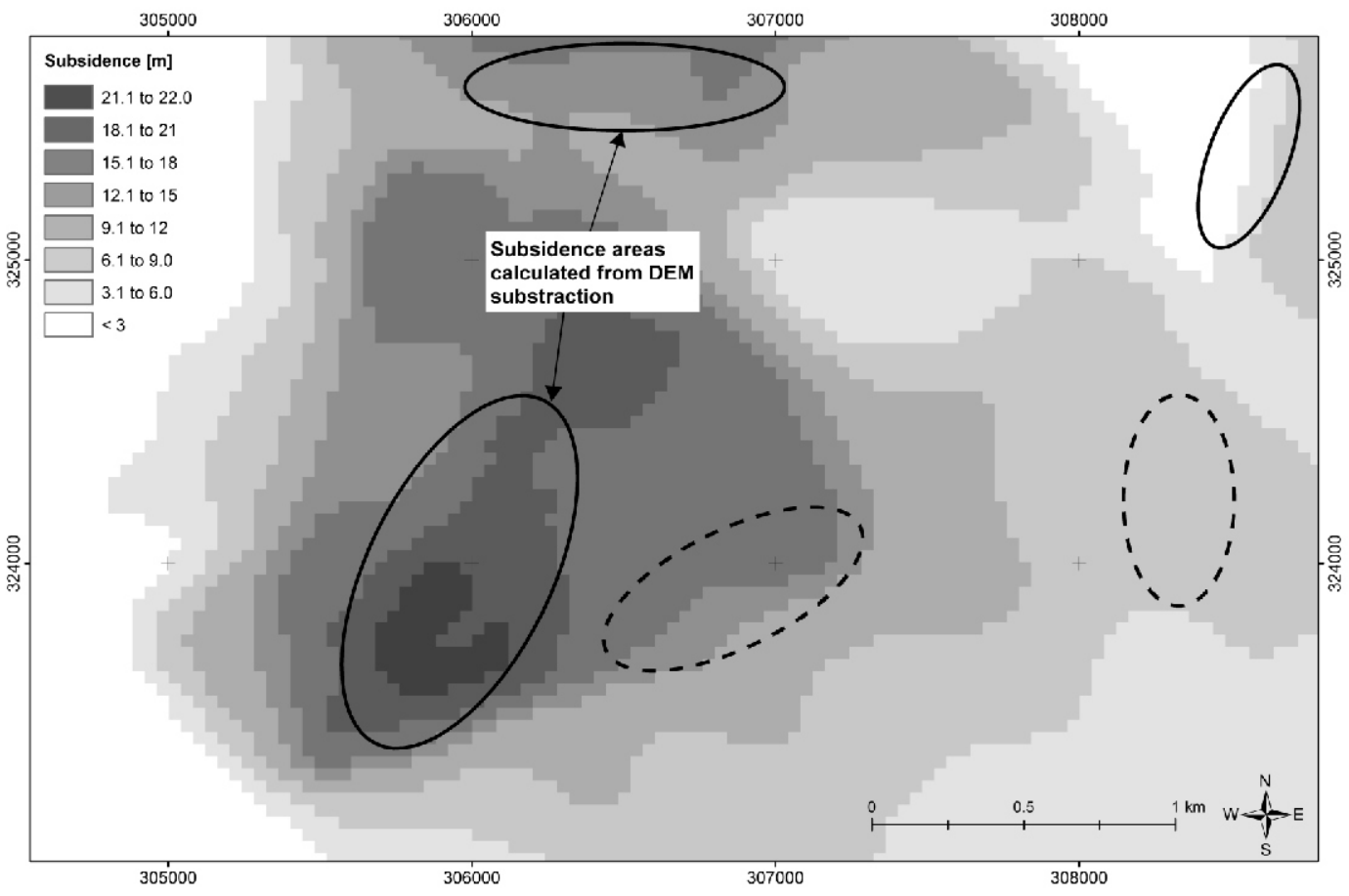

Fig. 12. Subsidence in area B, predicted using the modified Knothe method

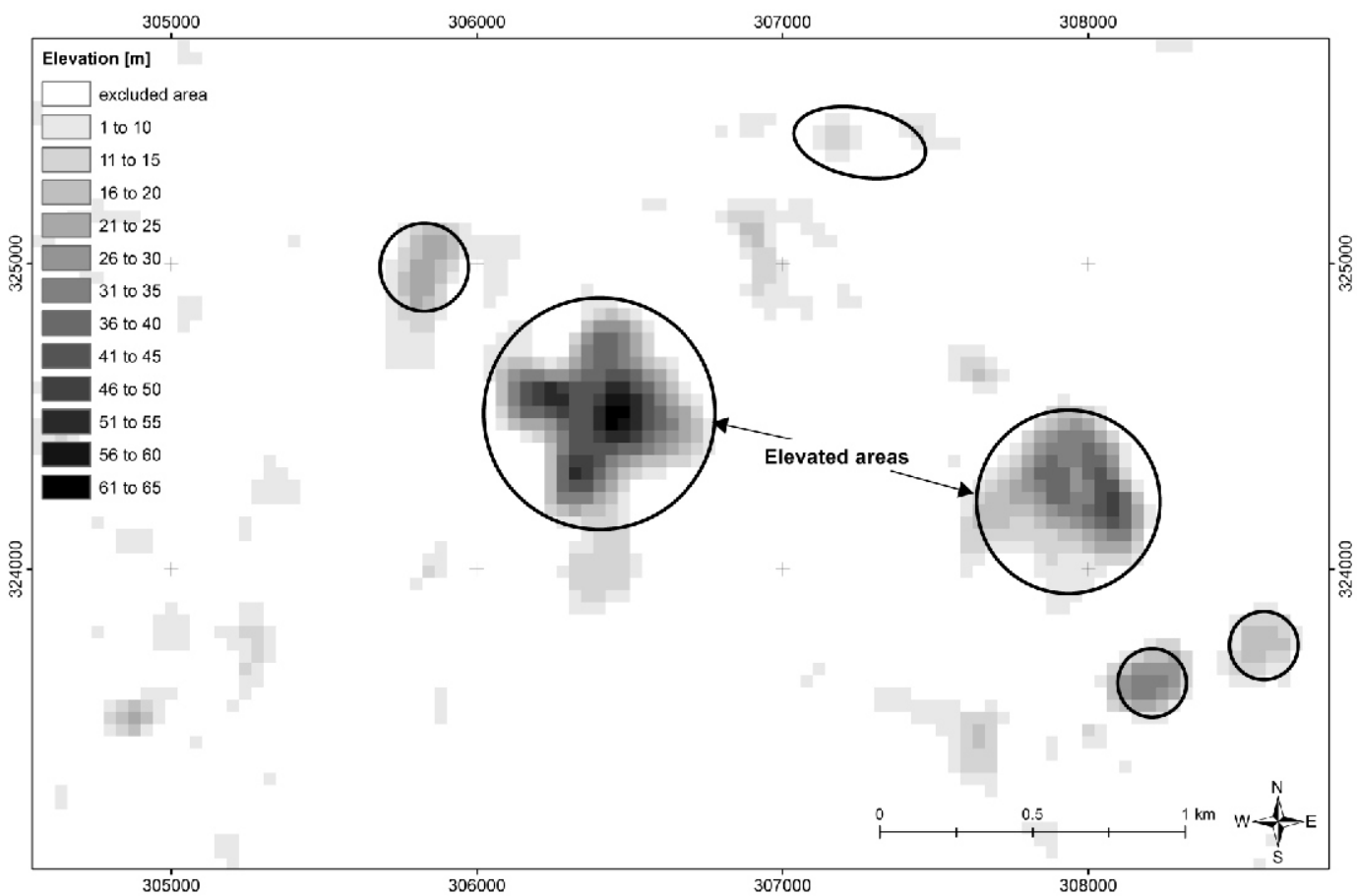

Fig. 13. Elevation in area $B$, calculated from subtraction of DEM raster maps 


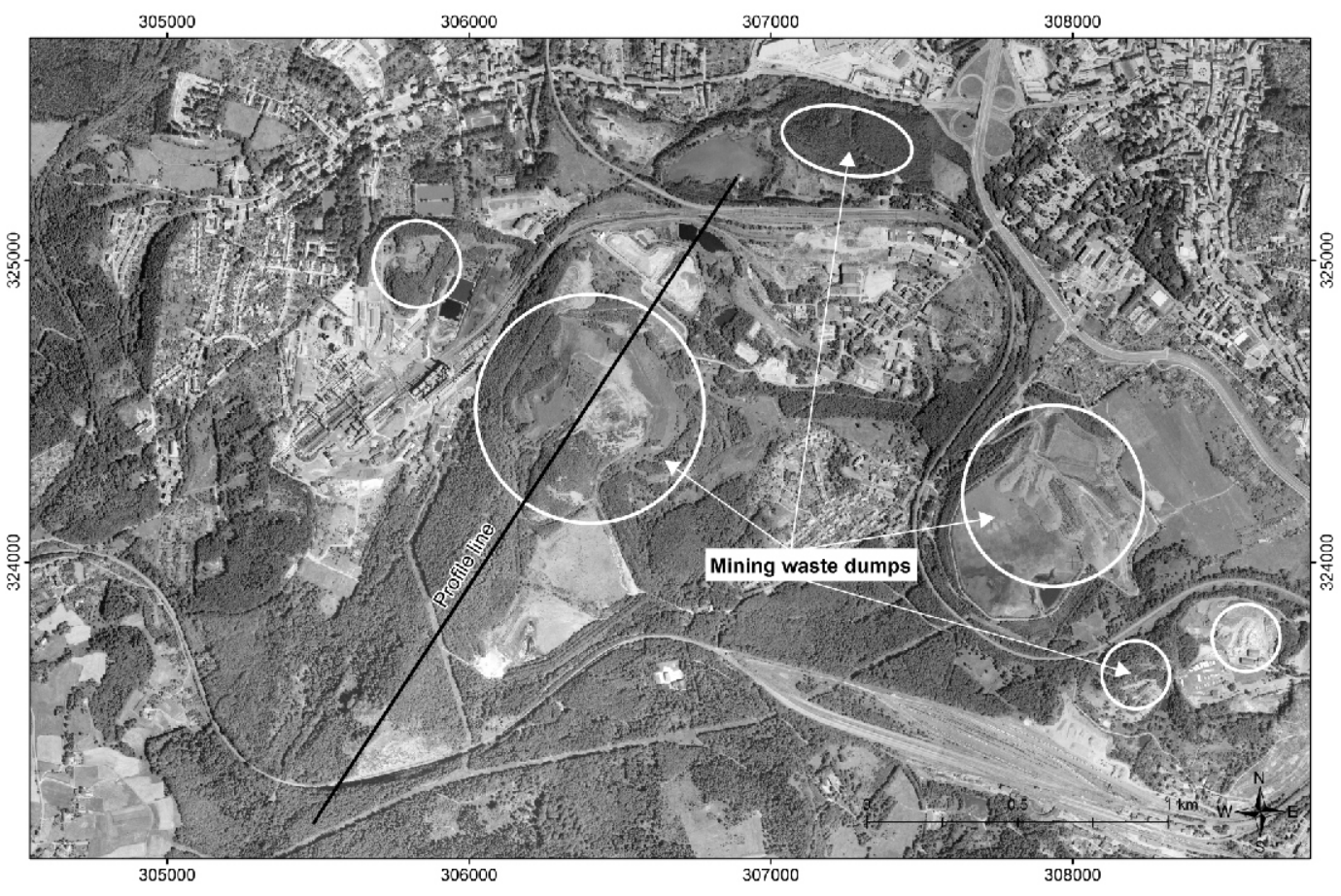

Fig. 14. Orthoimage showing present-day topography of area B

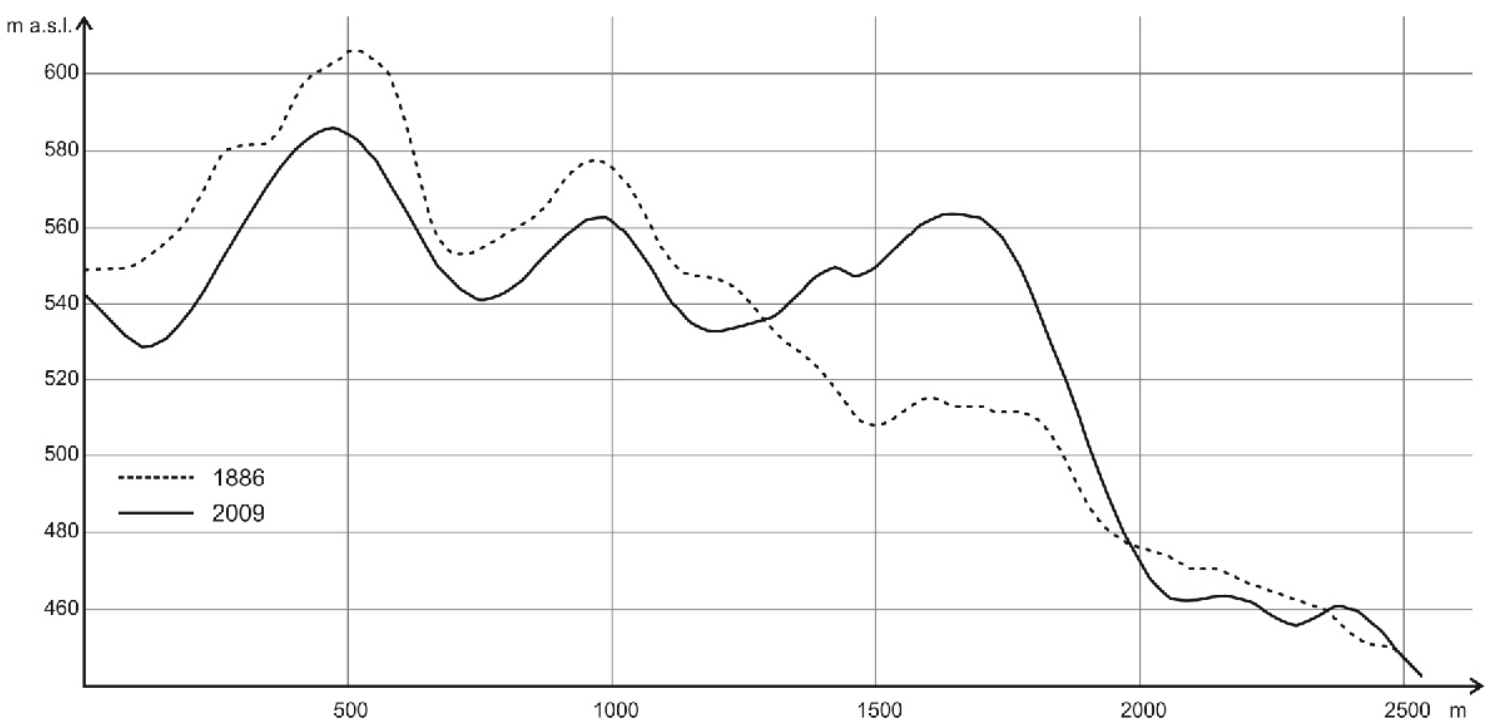

Fig. 15. Height of the surface in the years 1886 and 2009 along a profile line 
Coal Basin. The limitation arises from the need to choose the correct values of the method's main parameters, coefficient of mining (a) and angle of the range of influence $(\beta)$, to confidently predict subsidence of a large and complicated mining terrain. One should also remember that modelling of mining subsidence with the Knothe method does not take into account local variations and the development of large volumetric objects on the surface, such as waste dumps, and their influence on the form of the mining terrain.

The proposed GIS-based method may be a source of information to verify Knothe method results and to adjust the method's parameters, or can serve as a supplementary method and source of information. It should be used with the knowledge of its limitations arising, among other, from the accuracy of the source materials (topographic maps) and processing errors (e.g., scanning, digitising, format conversion).

\section{SURFACE TRANSFORMATION DUE TO LAND DEVELOPMENT}

An accompanying study focused on the identification of the extent of surface development in the 1886-2009 period.

The second aspect of this study was to analyse the land development process. With this aim, the spatial extents of built-up and developed areas in 1886 and 2009, derived from topographical maps and orthoimage, is presented in Figure 16 for area $A$ and in Figure 17 for area B. In 1886, the built-up area accounted for approx. 9 and $10 \%$ of the study areas A and area B, respectively. By the first decade of the 21st century, approx. 35 and $42 \%$ of the total land in areas $A$ and $B$ was taken up by de- velopment. It means growth by $377 \%$ for area $A$ and $436 \%$ for area $\mathrm{B}$. The size of transformed land is given in Table 3 .

\section{CONCLUSIONS}

The proposed method of spatial analysis based on cartographic modelling and map algebra in geographical information systems has allowed determining surface elevation changes for a period of 123 years of mining activity in a post-mining area (1886-2009). The method was applied in two areas of the Wałbrzych agglomeration in SW Poland. Areas of subsidence generated by the underground coal extraction and areas of elevation due to development of mining waste dumps have been identified and their magnitude determined. The calculated subsidence values reach $24 \mathrm{~m}$ in area $A$ and $36 \mathrm{~m}$ in area $B$, which is approx. 0.2 and $0.3 \mathrm{~m}$ per annum, respectively. The elevation changes reach $52 \mathrm{~m}$ for area $A$ and $63 \mathrm{~m}$ for area $\mathrm{B}$, and are associated with numerous waste dumps identified in the field and on the orthoimages.

Comparison with the results of subsidence predictions obtained with the modified Knothe method (Kowalski and Jędrzejec, 2000) has revealed good correlation between the two solutions, 0.90 and 0.69 for areas $A$ and $B$, respectively. Furthermore, the subsidence values obtained with the GIS method are higher and less uniformly distributed. It may be to the fact that the Knothe method requires careful selection of parameters for subsidence prediction in areas of complex geological and mining conditions, such as the Wałbrzych Coal Basin area.

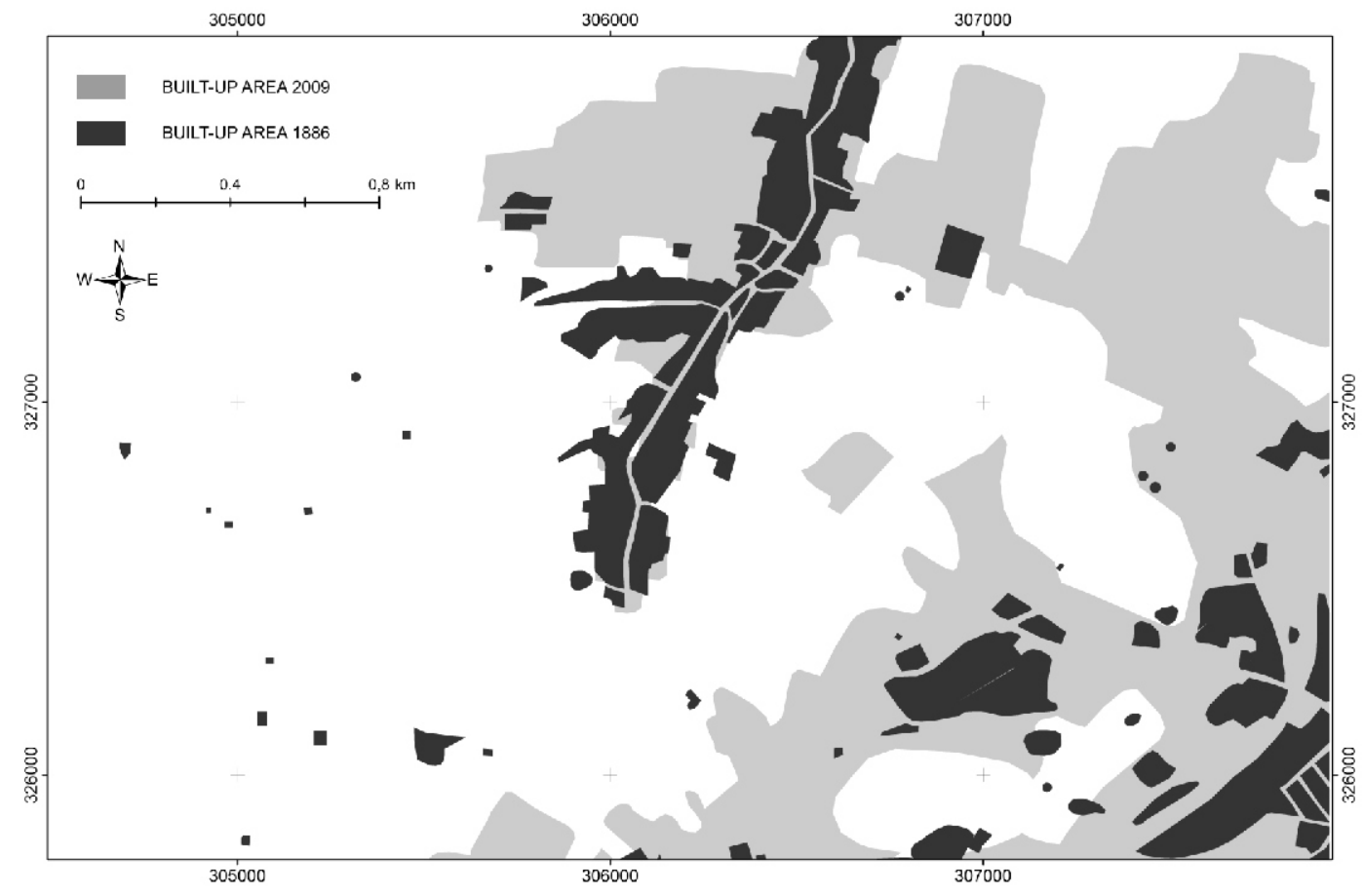

Fig. 16. Analysis of surface transformation due to land development between 1886 and 2009 in area A 


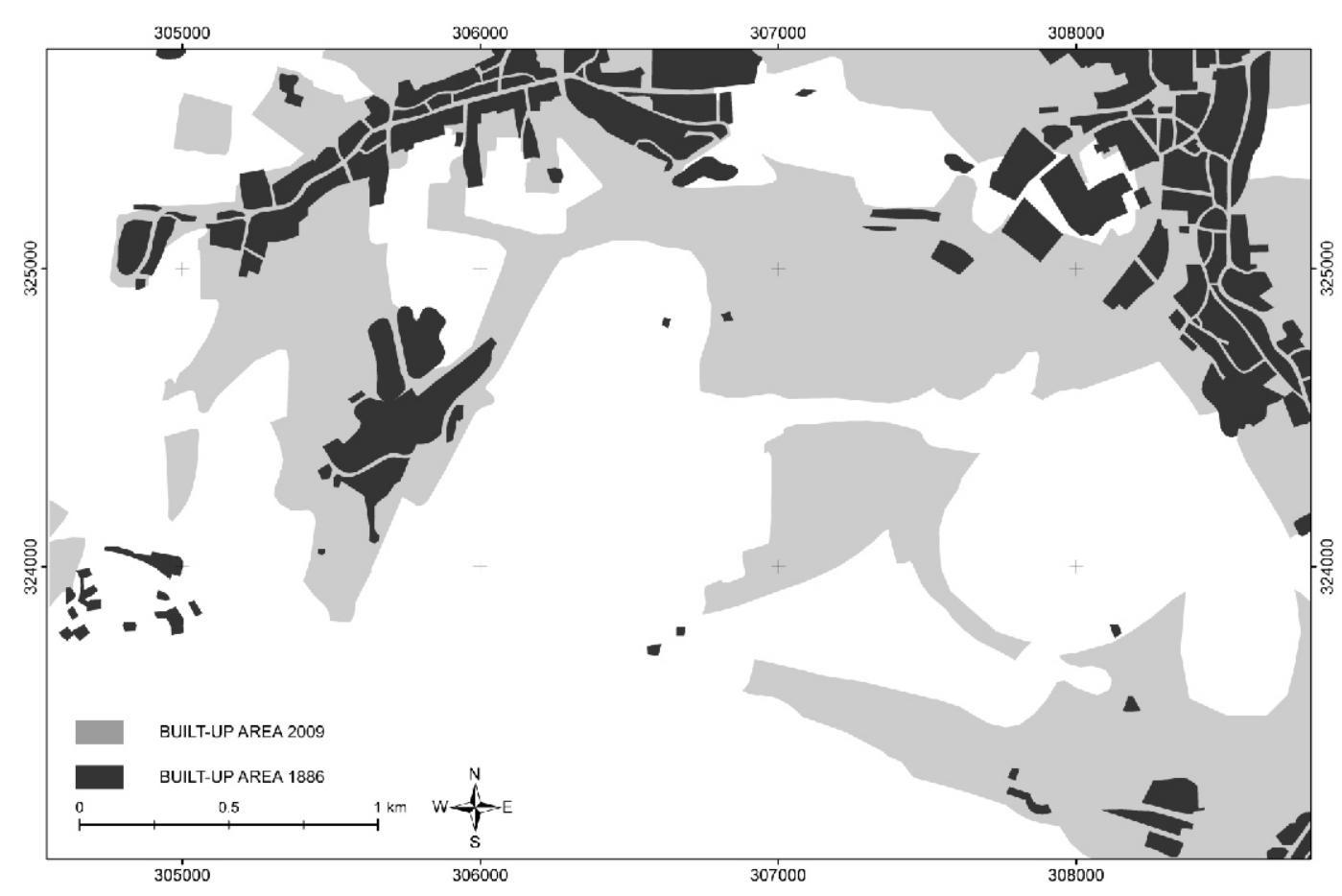

Fig. 17. Analysis of surface transformation due to land development between 1886 and 2009 in area B

Built-up area in the period 1886-2009

\begin{tabular}{|c|c|c|c|c|}
\hline Year & $\begin{array}{c}\text { Area } \\
{\left[\mathrm{m}^{2}\right]}\end{array}$ & $\begin{array}{c}\text { Area change } \\
{\left[\mathrm{m}^{2}\right]}\end{array}$ & $\begin{array}{c}\text { Area change } \\
{[\%]}\end{array}$ & $\begin{array}{c}\text { Share of total area } \\
{[\%]}\end{array}$ \\
\hline \multicolumn{7}{|c|}{ Area A } \\
\hline 1886 & 697,956 & - & - & $35 \%$ \\
\hline 2009 & $2,632,499$ & $1,934,543$ & $377 \%$ & $10 \%$ \\
\hline \multicolumn{7}{|c|}{ Area B } \\
\hline 1886 & $1,303,073$ & - & - & $42 \%$ \\
\hline 2009 & $5,684,425$ & $4,381,352$ & $436 \%$ & \\
\hline
\end{tabular}

The GIS method used for this study allows determining mining terrain subsidence caused by long-lasting coal mining over a large area and analysing ground height changes that occurred in the past, when sources of height information other than topographical maps are unavailable. It is also a good tool for evaluation of subsidence values predicted with empirical methods.

In addition to scientific applications, the results may also be a valuable source of information for local administration and spatial planning services in carrying out their tasks related to monitoring the condition and new development of post-mining grounds.
Acknowledgements. This work has been financed from the National Science Centre Project UMO-2012/07/B/ST10/04297 "Development of a numerical method of mining ground deformation modelling in complex geological and mining conditions" and the scientific project No S30035 "Development of the model of secondary deformations on mining grounds executed" at the Institute of Mining Engineering of the Wroclaw University of Technology (Poland). We would like to express our sincere thanks and appreciation to the editor and anonymous reviewers, whose accurate comments have led to improvement of this paper. 


\section{REFERENCES}

Białek, J., Mielimąka, R., 2001. Próba weryfikacji parametrów teori prognozowania wpływów eksploatacji na teren górniczy (in Polish). Zeszyty Naukowe Politechniki Śląskiej, 250: 69-79.

Blachowski, J., 2008. Geographical information system of the Wałbrzych underground coal mines a way to improve effectiveness and accuracy of mining grounds deformation studies (in Polish with English summary). Prace Naukowe Instytutu Górnictwa Politechniki Wrocławskiej. Studia i Materiały, 123 17-27.

Blachowski, J., Stefaniak, P., 2012. Development of the geoinfomation system of the former Walbrzych underground hard coal mines (in Polish with English summary). Prace Naukowe Instytutu Górnictwa Politechniki Wrocławskiej. Studia i Materiały, 135: 5-21.

Bolstad, P., Smith, J., 1992. Errors in GIS. Journal of Forestry, 90 $21-29$.

Choi, J.K., Kim, K.D., Lee, S., Won, J.S., 2010. Application of a fuzzy operator to susceptibility estimations of coal mine subsidence in Taebaek City, Korea. Environmental Earth Sciences, 59: 1009-1022.

Djamaluddin, I., Mitani, Y., Esaki, T., 2011. Evaluation of ground movement and damage to structures from Chinese coal mining using a new GIS coupling model. International Journal of Rock Mechanics and Mining Sciences, 48: 380-393.

Esaki, T., Djamaluddin, I., Mitani, Y., 2008. A GIS-based prediction method to evaluate subsidence-induced damage from coal mining beneath a reservoir, Kyushu, Japan. Quarterly Journal of Engineering Geology and Hydrogeology, 41: 381-392.

ESRI, 2010. ArcGIS 10 Desktop Help. Professional Library - Spatial Analyst.

Hutchinson, M.F., Dowling, T.I., 1991. A continental hydrological assessment of a new grid-based digital elevation model of Australia. Hydrological Processes, 5: 45-58.

Jarosz, A., 2005. Using DInSAR to Monitor Subsidence Caused by Underground Mining Utilising Block-Caving Method. Proceedings ESA International Workshop on ERS SAR Interferometry, Frascati (Rome), Italy, 28 Nov.-2 Dec 2005.

Jędrzejec, E., Kalisz, P., Kowalski, A., Kwiatek, J., 2008. New solutions in the field of surface deformation prediction and object protection in mining areas (in Polish with English summary). Gospodarka Surowcami Mineralnymi, 24: 62-73.

Knothe, S., 1984. Prognozowanie wpływów eksploatacji górniczej (in Polish). Wydawnictwo Śląsk, Katowice.

Kominowski, K., 2000. Geologia i hydrogeologia (in Polish). In: Eksploatacja górnicza a ochrona powierzchni. Doświadczenia z wałbrzyskich kopalń (ed. A. Kowalski): 33-48. Central Mining Institute, Katowice.

Kowalski, A., ed., 2000. Eksploatacja górnicza a ochrona powierzchni. Doświadczenia z wałbrzyskich kopalń (in Polish). Central Mining Institute, Katowice.

Kowalski, A., 2008. Przykłady porównania prognozowanych z pomierzonymi wskaźnikami deformacji powierzchni (in Polish). Przegląd Górniczy, 64: 35-44.

Kowalski, A., Jędrzejec, E., 2000. Zagrożenia powierzchn spowodowane dokonana działalnościa górniczą i likwidacja kopalń (in Polish). In: Eksploatacja górnicza a ochrona powierzchni. Doświadczenia z wałbrzyskich kopalń (ed. A Kowalski): 343-366. Central Mining Institute, Katowice.

Kożuchowicz, S., Oprychał, J., 1984. Dokumentacja geologiczna złoża węgla kamiennego KWK Wałbrzych (in Polish). Przedsiębiorstwo Geologiczne we Wrocławiu.
Kratzsch, H., Fleming, R., 2011. Mining Subsidence Engineering. Springer-Verlag.

Lee, S., Park, I., Choi, J.K., 2012. Spatial prediction of ground subsidence susceptibility using an artificial neural network. Environmental Management, 49: 347-358.

Majcherzyk, T., Kryza, K., 2013. Analysis of measured and predicted land surface subsidences caused by retreat mining. Studia Geotechnica et Mechanica, 35: 143-156.

Malinowska, A., 2011. A fuzzy inference-based approach for building damage risk assessment on mining terrains. Engineering Structures, 33: 163-170.

Malinowska, A., Hejmanowski, R., 2010. Building damage risk assessment on mining terrains in Poland with GIS application. International Journal of Rock Mechanics and Mining Sciences, 47: 238-245.

Mathey, M., 2013. Addressing the challenges involved with abandoned underground coal mines in South Africa. XV International ISM Congress 2013 Proceedings: 113-123.

Oh, H.J., Lee, S., 2010. Assessment of ground subsidence using GIS and the weights-of-evidence model. Engineering Geology, 115: 36-48.

Oh, H.J., Lee. S., 2011. Integration of ground subsidence hazard maps of abandoned coal mines in Samcheok, Korea. International Journal of Coal Geology, 86: 58-72.

Oh, H.J., Ahn, S.Ch., Choi, J.K., Lee, S., 2011. Sensitivity analysis for the GIS-based mapping of the ground subsidence hazard near abandoned underground coal mines. Environmental Earth Sciences, 64: 347-358

Preusse, A., Kateloe, H.J., Sroka, A., 2008. Future demands on mining subsidence engineering in theory and practice. Gospodarka Surowcami Mineralnymi, 24: 15-26.

Samsonov, S., d'Oreye, N, Smets, B., 2013. Ground deformation associated with post-mining activity at the French-German border revealed by novel InSAR time series method. International Journal of Applied Earth Observation and Geoinformation, 23: 142-154.

Serdyńska-Iwaniuk, L., 1984. Dokumentacja geologiczna złoża węgla kamiennego KWK Victoria (in Polish). Przedsiębiorstwo Geologiczne we Wrocławiu.

Stecchi, F., Mancini, F., Ceppi, C., Gabbianelli, G., 2012. Vulnerability to ground deformation phenomena in the city of Tuzla (BiH): a GIS and multicriteria approach. Natural Hazards, DOI: 10.1007/s11069-012-0225-2

Tomlin, C.D., 2008. Cartographic Modelling. In: Encyclopedia of Geographic Information Science (ed. K.K. Kemp). Sage.

Wójcik, J., 2006. The development of the anthropogenic relief from the coal mining industry in the Wałbrzych Basin on the ground of the management of waste materials from coal mining in 1975-1996 (in Polish with English summary). Przegląd Geograficzny, 78: 109-126.

Wójcik, J., 2008. Surface change due to mining in the Walbrzych area (in Polish with English summary). Landform Analysis, 9: 339-342.

Zahiri, H., Palamara, D.R., Flentje, P., Brassington, G.M., Baafi, E., 2008. A GIS-based Weights-of-Evidence model for mapping cliff instabilities associated with mine subsidence. Environmental Geology, 51: 377-386. 